\title{
Lexion: That Which Upholds or Bears an Archetype Introducing Lex and Lexion to Modern English
}

\author{
Helen Russ \\ School of Business Western Sydney University, NSW Australia \\ E-mail: H.Russ@westernsydney.edu.au / helen@helenruss.com
}

Doi:10.7575/aiac.alls.v.6n.6p.94

Received: 18/07/2015

URL: http://dx.doi.org/10.7575/aiac.alls.v.6n.6p.94

Accepted: 07/09/2015

\begin{abstract}
Derived from the Etruscan and Greek alphabets, Latin is a classical language that has influenced modern languages such as English, French, Italian and Spanish. With its Latin and Greek roots, this paper argues that the word lexion is an appropriate and necessary addition to the English language. Lex in Latin means, law, syllabus, statute and dharma. Lex in Ancient Greek means 'the Word' or logos. Drawing from Plato, this paper argues that lexion is the lore, law and dharma that upholds or bears an idea or perfect Form. A lexion emerges at the confluence of forces aligned with the archetype, thus forming the metaphysical body or spirit of an organisation. It is argued that a new term is necessary to name this phenomenon as current terms, while appropriate in some contexts, are often inadequate, limited and at times misleading. This paper outlines the benefits in introducing a new term.
\end{abstract}

Keywords: archetype, lex, lexion, metaphysical, organisational spirit, Plato

\section{Introduction}

In The Republic, Plato argued that behind physical phenomenon are perfect Forms or archetypes (Jowett, 1891, Book V11, p.1165; Louth, 2007). Perfect Forms exist in a non-dimensional, less emanated (incarnated) level of creation. They are the divine blueprint or essence of what we experience with the physical senses (Louth, 2007; Sagan 2007; Miller, 1974; Jowett, 1891).

This paper argues that a term is needed. Through the process of emanation, a perfect Form will be upheld by lore, laws and dharma that support, bear and shape its emanation (Russ 2014). At the confluence of forces aligned with the perfect Form a new 'form' emerges. Drawing from Latin and Ancient Greek, this paper names lexion as what upholds or bears an idea or perfect Form (lex). This paper outlines the traditional meaning of lex, from both Greek and Latin, to renew its use for a modern audience. It defines the modern definition of lex and lexion. Terms such as the corporate being (Sagan, 2007), metabeing (Bodeau, 1999), egregore, (Delaforge, 1988) a psychic entity (Dubuis, 2000), corporate angel (Wink, 1986), the metaphysical body (Russ, 2014), the super-organism (Bloom, 1995) and meme (Dawkins, 2006), have been used to describe the phenomenon being considered. This paper discusses why these terms are inadequate and what are the benefits in the introduction of a new term.

\section{Definitions}

'In the Beginning was the Word, and the Word was with God, and the Word was God'

(John 1:1, King James Version).

This paper introduces new terminology by utilising the original meaning of 'The Word', as creative emanating principle and the original meaning of 'law' as the principle of order and structure. The words lex and lexion are re-introduced by drawing on the original Greek and Latin definitions. The nature of this research demands an explanation of the origins of the term lex. While original definitions of 'The Word' and 'law' are important in defining the meaning of the term Lex, the current scholarly discourse around meanings, definitions and appropriate usage is exhaustive. As this discourse draws from the original definitions the discussion will be limited as such.

Definitions of 'The Word' can be traced to esoteric, religious and philosophical sources at least into early Ancient Greek times in the work of Heraclitus and Plato (Jowett, 1891; Singh, 1963). In Greek lexis originally meant 'speech' or 'word' (Harper, 2014). Lexicon was used to describe a compendium of words. Lexicology was the study of words and a lexicon was the preferred word for dictionary in Greek, Syriac, Hebrew and Arabic (Harper, 2014). Lex relates to the Greek lexikos, meaning 'of or for words', lego meaning 'to say', and logia meaning 'the study of' (Liddell, 1940; Harper, 2014). According to Liddell, lex is derived from the suffix logos meaning speech, oration, discourse, quote, study calculation and reason. Esoteric interpretations of logos define it as the 'divine Word' or emanating principle (Harper, 2014; Sagan, 2007). The meaning behind lex in Greek refers to both the 'regular word' used in every day speech and a metaphysical definition of 'The Word' or logos referring to the divine emanating principle.

The Latin word lex is described as 'law, precept, regulation, principle, rule, mode or manner'. It is also described as a covenant, agreement, a condition or stipulation (Lewis, 1891, p.468; Smith, 1855, p.328). The Phraseological Latin- 
English Dictionary defines lex as 'a law, proposed or enacted, a rule or regulation and a condition' (Yonge, 1856, p.291). By the 1500s lex was defined as a system or body of laws, a particular or specified law (Collins English Dictionary, 2015; Ruby, 1986), but the term has much older roots. In the Bible lex was used as a prefix to laws. For example, in Ecclesiastes the Ten Commandments are referred to as the Lex Mosi or the Law of Moses crystallising the law of God into simple instructions (McCullough, 1981). In Ancient Rome, lex was also used as a prefix to enacted laws. For example, Lex Valeria (509-300 BC) granted Roman citizens the legal right to appeal against a capital sentence (Lentz, 1993). Lex Regia, were royal laws used and enacted by the kings of ancient Rome who held the roles of political, military, religious and judicial chief (Watson, 1991). In ancient Rome, the word lex preceded any legal ruling.

Singh (1963) suggests it was Heraclitus (535-475 BC) who first spoke philosophically of the idea of law but he argues that the idea of law was integrated into earlier works of Homer $\left(8^{\text {th }}\right.$ century BC) and into the Ionian ideas $\left(8^{\text {th }}-6^{\text {th }}\right.$ century BC) about world-order, the Pythagorean concepts (570-495 BC) of measure, cosmos and the legal structuring of society. St Augustine, a Roman philosopher (354-430 AD) was aware of the writings of Cicero (107 BC-44 AD) when he discussed lex aeterna (or cosmic logos) describing an eternal law (Chroust, 1973; Singh, 1963). Much later Erasmus discusses the law of God as lex aeterna, lex Divirza and, lex Dei (McCullough, 1981, p.91). The original essence of the word 'law' appears to refer to eternal, cosmic or divine laws; laws that are immutable, unchangeable or eternal and govern the unfolding cosmos.

Finally from Hindu philosophy 'dharma' has been translated as 'law' (Rocher, 1977). 'Dharma' is a Sanskrit word meaning 'to hold, maintain, keep'. It is also defined as what is established or firm and therefore law. 'Dharma' is a complex term encompassing meanings of right conduct, duty, social justice, ethos, custom, quality, model and responsibility (Arokiasamy, 1986, p.17; Horsch, 2004; Ramkumar, 2010). It is derived from an older term from Vedic Sanskrit meaning bearer or supporter (of deities) and in a religious sense it is seen as a reflection of Rta (Day, 1982). In a similar way to 'law', 'dharma' is the principle that remains constant and in so doing it regulates the course of change. It is also that which upholds or bears the law.

The paper argues that sourcing the esoteric essence of the term lex from both Greek and Latin leads to similar phenomena. Interpreting the work of Plato and Heraclitus particularly suggests that the archetypal meaning of 'law' and the archetypal meaning of 'The Word' refer to the creative power that structures creation. To understand the intellectual standpoint behind this interpretation, it is necessary to provide a context.

\section{The context}

Plato described creation as levels of emanation from 'The One' (Jowett, 1891; Louth, 2007; Miller, 1974; p.xxxixxxiii). 'The emanation model is a basic aspect of Platonic, neoplatonic and Kabalistic theory, according to which God created the universe through a process of emanation, or radiation' (Coudert, 1995). A Platonic cosmology embodies 'The One' or 'The Good', which is an eternal unity beyond duality. It is pure spirit, a non-dimensional reality with no time, space or gravity (Sagan, 2007; Miller, 1974; Leadbeater, 1902). 'The One is truth ineffable, one touches it, one is united with it by theoria, but one cannot define it' (Louth, 2007, p.5). The second dimension was described by Plato as comprising intelligible (or intermediary) realms embodying the logos or understanding (Langlois, 1971) where attention is the focusing force (Palmer, 1994). They are fluid dimensional and non-dimensional realms governed by laws of duality, where laws of time and space are not fixed (Heindel, 1909). The third dimension is material creation or dimensionality. This level is the visible world, where gravity is the focusing force and laws of limits, time and space apply (Leadbeater, 1902; Besant, 1912). Plato argued that what we experience with the physical senses is an emanation of a perfect Form from the world of Ideas (intelligible realms) (Jowett, 1891; Louth, 2007; Rommen, 1998). Confirmed in ancient Indian texts (Rgv. X65.7) Miller (1974) says that, 'one aspect is manifested on earth, but the real or vital essence remains invisible' (p.14).

'The One' described by Plato is immutable, unchangeable, eternal and infinite in its multiplicity (Jowett, 1891, p.676; Miller, 1974, p.xxxiii). The essential unity of all 'Being' is stressed by Heraclitus in his fragment 'One out of all and all out of One' (Singh, 1963, p.42). The world of Ideas or perfect Forms embody the natural unity of 'The One'. Emanation occurs when Will aligns with a perfect Form or archetype and a reflection of the Form emerges in creation (Russ, 2014; Miller, 1974, p.xxxi). Each emanation carries the essence of first principles, rules, patterns or laws that make it so, that govern its existence, that shape its being. Each emanation reflects 'the laws' (lex aeterna) within the world of Ideas, the perfect structure that upholds the perfect Forms.

\section{The importance of names}

In Cratylus Plato argues that names are linked to the essence of things, to their essential or eternal nature (Jowett, 1891, p.365-424). Plato suggests that 'true' names are first principles aligned with the world of Ideas. True names are living forms, connected to their perfect Form. According to Beck (1995), the biblical Adam knew 'the intrinsic nature' of things and gave names to worldly phenomenon by translating the divine eternal word. The 'Adamic signatures can still be partially read in the words we use for things'(p.58). Beck also argues that the Hindu tradition suggests that 'individual letter potencies (sakti), ....leave an impression or trace (samskara)' (p.61). According to Plato, the shape, sound and structure of letters and syllables are linked to archetypal essences in intelligible realms (the world of Ideas) (p.372-4). 'Each word ... was the inner specific character or essence of its respective reality' (Beck, 1995, p.58).

The act of naming something facilitates its emanation. Wolfson (1970) quotes Athanasius when he says that 'the Word, is a "generated being" ( $\gamma \varepsilon \dot{v} \vee \eta \mu \alpha)$ or a "son" and, as such, he is "the proper offspring ( $\gamma \dot{\varepsilon} v \vee \eta \mu \alpha)$ of the essence," (p.53). The name is the living form in creation that reflects the harmony in archetypal realms. In the Bible, Adam's commission 
is to name worldly phenomenon. 'To know is to name; to name is to know;' (Ryken, Wilhoit, Longman III 2010, p.10). In Kabbalah there is a 'direct relationship between letters, names, words and essence'. 'God in one fashion or another created the world using language' (Katz,1995, p111). By naming, there is emanation. The 'Word' is a living Form, it is shape and sound aligned with an archetype. According to Plato, words are instruments and an instrument used in alignment with its true Form brings harmony (Jowett 1891, p.372). True names' have potency, they are connected to 'The One' (Jowett, 1891; Louth, 2007), indicating the importance of names that are aligned with archetypal realms.

Plato also argues that the true nature of things cannot be known without studying the phenomenon beyond its name (Jowett 1891, p372). According to Russ (2014), Miller (1974), Sagan (2007) it is possible to explore the interior essence of phenomenon through a process of internalisation of consciousness. Metaphysical mapping described by Russ (2014, p.145-149) sources the archetypal essence behind material phenomenon. In Cratylus Socrates claims that words in different languages can be sourced to similar archetypal essences the the same way an awl made from different iron is still drawing from the essence of awl-ness (Jowett 1891, p.372). This paper argues that the archetypal essence of the terms, 'law' in Latin and 'The Word' in Greek can be traced to the term, lex which, it is argued are referring to similar phenomenon.

\section{Linking 'The Word' and 'the Law'}

Since Plato (428-348 BC) at least, the concept of law has been linked to the quest for virtue which means being aligned with the perfection in the world of Ideas (McCullough, 1981; Lewis, 2008 p.633). Kessler (1944) argues that Plato's objective realism rests on his faith in the existence of 'absolute values [or in] the reality of Ideas, as the cause of true being and true knowledge' (p.35). Kretzmann (1988) quotes Cicero when he says that, 'the very definition of the term "law" inheres the idea and principle of choosing what is just and true' (p.100). According to Plato the engine driving harmony within the world is the quest for virtue resting on principles of justice (McCullough 1981, Jowett 1891, Rommen, 1998; Kessler, 1944). Justice is achieved through the principle of reason which is known by being aligned with the world of Ideas. 'The just law of the perfect state flows from the principle of reason (logos) by a process of logic (dialectic)'(Kessler, 1944 p.37). Miller (1974) suggests that the divine statutes of law can be traced to 'the cosmic order' and 'the right reflecting of which brings well-being' (Miller, 1974, p.51; Ruby, 1986). In essence 'true law' is embedded within the perfection of the world of Ideas. Heraclitus (frag 91) confirms, 'human law partakes of the law of nature, which is at the same time a divine law' (Singh, 1963, p.467; Ruby, 1986). The quest for law is a quest for the perfection and harmony of the world of Ideas.

Esoteric scholars suggest that 'the Word' or logos is the first emanating principle (Miller, 1974). The creative power with which the divine manifests the creation (Word, Sagan, 2007). 'The Word' (lex) to Heraclitus was the principle of order and knowledge, that gives structure to the creation. According to Singh (1963) 'The Word' is what Heraclitus (535-475 BC) calls the logos, "the principle of "fixed measure" which governs the Cosmos' (p.462). The Stoic philosophers identified the term with the divine emanating principle pervading the universe (Rommen, 1998). It is argued that the 'fixed measure' described by Heraclitus is what Plato described as a perfect Form or archetype. The archetypal essence of 'the law' (lex) is embedded within the perfection and harmony in the world of Ideas or the world of archetypes.

To western esoteric philosophers 'the Word' (lexis) is a creative force from which the creation emanates (Miller, 1974; Sagan, 2007; Besant, 1912). It is the divine emanating principle. 'In the Beginning was the Word' (John 1:1, Bible, King James Version). Lex is therefore the principle of emanation. This paper argues that lex is the emanating perfect Form, with embedded patterns, rules or laws.

This paper argues that 'The Word', logos (lex) is an archetype in emanation through the power of Will and 'the law' (lex) is the structure, or archetypal patterning embedded within an emanation. It suggests that at their esoteric source, 'The Word', logos (lex) and 'the law' (lex) are synonymous. Heraclitus said that "'the Word" or logos, the principle of "fixed measure" which governs the Cosmos, [and] the law that regulates the entire natural and human order are fundamentally identical' (Singh, 1963, p.462). Rommen (1998) also links them when he says that "the 'law" emanates from the logos, which in turn is itself "the law" of things' (p.36). 'The law' is 'The Word', and 'The Word' is 'the law'. 'The Word' or logos (lex), the emanating principle, is the fixed measure or law (lex) that governs the cosmos.

\section{Lex and Lexion in English}

By taking advantage of the original Latin words for 'law', and Greek word for the 'creative word' or logos and to and prevent confusion with the modern definitions, the term lex is used. For the purposes of this discussion lex is the emanating force from (what Plato defined as) the world of Ideas. A lex is an emanating archetype. A lexion is defined as that which upholds the lex. A lexion is the metaphysical essence behind the visible laws, lore, dharma, conditions, behaviours, rules, beliefs, desires, patterns, principles and conditions that uphold and bear a perfect Form. The lexion is the metaphysical vehicle for the lex. The lex is perfect, pure, in harmony with the unity of 'The One'. It is a force that by its very nature it embodies cosmic, divine or natural laws or principles. Each lex is a emanation of a perfect Form, expressing itself. The lexion emerges as convergent Will forces align with the emanating perfect Form.

For the purposes of this discussion, lex refers to 1) the eternal, immutable principles behind the laws that govern creation such as the law of gravity, the law of the seasons, the law that defines the growth patterns of a seed, the cycle of life and death, the laws of mathematics, astronomy, physics and geometry; 2) it refers to the essential perfect Forms behind laws constructed by the State, religions and the individual designed to move towards harmony, 3) it refers to the 
perfect Forms behind the lore or body of knowledge that a group holds about traditions, behaviours, obligations and rights.

Lex is the archetype in motion, it is the emanating principle, emerging in response to a vacuum, a lack, an emptiness or a lack of fullness. The lex is the 'perfect' response to the vacuum, activated by Will forces aligned with its perfect Form. The lex remains constant while emanating. The lexion forms as Will forces align with the lex. By definition, the lexion is the metaphysical form which holds, supports and bears that which remains constant and in so doing regulates the course of change. The lexion is the metaphysical body that carries bears and upholds the lex within intelligible realms. It is often recognised as the essence or spirit behind an ideology or group.

Take Rock and Roll, for example. Rock and Roll is a movement, a music style, a way of life, an attitude. For Rock and Roll to exist in creation, in the world of Ideas as defined by Plato, there must be an archetype or perfect Form of Rock and Roll-ness. Something divine, eternal, immutable and cosmic. Something that is unchanging and perfect. Something that is the pure essence of Rock and Roll-ness. The Rock and Roll lex is the emanating perfect Form. The Rock and Roll lexion emerges as multiple forces of Will align with the Rock and Roll lex facilitating emergence. The archetype 'is', the lex 'is becoming'. The lexion upholds, bears and supports the emanating lex.

In a similar way, an organisation established to 'serve' is a reflection of a lexion that emerges from the confluence of forces aligned with the perfect Form or archetype of 'service'. Experientially the organisational lexion is the essence behind the beliefs, attitudes, behaviours, lore, laws, dharma, mental frameworks, rules, patterns and customs that uphold and bear the organisational lex. It is the metaphysical body behind the visible artefacts of culture. It is beyond the scope of this research to present a detailed model of the phenomenon that is a lexion, its behaviour, nature and metaphysical structure. The work of Russ (2014), Bodeau (1999) Wink (1986) and Sagan (2007) can be researched in detail and are discussed briefly below.

\section{Previous studies}

The phenomenon of a lexion is not new. Within Western esoteric literature, but also drawing on the work of western philosophy, psychology and sociology, researchers have discussed the phenomenon using different names. For example, corporate being (Sagan, 2007), metabeing (Bodeau, 1999), egregore, (Delaforge, 1988) a psychic entity of a group (Dubuis, 2000) corporate angel (Wink, 1986), the metaphysical body of an organisation (Russ, 2014) and meme and meme-complex, (Dawkins, 2006) are all terms used to describe the phenomenon being discussed.

Scholars within the western esoteric tradition have described the concept of the lexion. Bodeau (1999) defines what she calls the 'metabeing' as the composite or collective consciousness within societies, groups and organisations. Bodeau's work focuses on becoming aware of the 'metabeing'. She considers it important that people become responsible for their role within it, as organisational dysfunction can be linked to the health and harmony of the 'metabeing'. Sagan (2007) describes 'corporate beings', as astral beings that manipulate the functioning of organisations. Sagan discusses corporate culture and describes the influence of upper currents (world trends or emotional waves) that affect the harmony and destiny of organisations. The western esoteric tradition refers to an 'egregore' or the psychic entity of a group (Dubuis, 2000, p.8; Delaforge, 1988, p.6), primarily relating to traditions such as the Masonic Lodge, esoteric orders and churches. These groups wanted to understand the relationship between individuals and the consciousness of the group with the goal of maintaining organisational integrity. From similar western esoteric roots, Wink (1986), a theologian, draws on the work of Jung to describe the 'corporate angel' which encompasses the public face of organisations and the shadow. Similar to Bodeau, Wink encourages members of the organisation to consciously address the 'corporate angel' actively. The focus of these writers is to develop an active conscious dialogue and exchange between the spirit of the organisation and individual members (Russ, 2014). The primary motive is integrity of the group in the long term.

In 1976, drawing from principles of genetics, Dawkins coined the term 'meme' as a unit of cultural transmission and 'meme-complex' to refer to a stable set of memes working in concert (2006, p.192-6). Memetics is a theory without a methodology (Aunger, 2006; Edmonds, 2002; Rose, 1998). It draws analogies with principles of genetics to suggest that memes, like genes, rest on principles of replication, longevity, fecundity and imitation (Wilkins, 1998; Brodie, 1996). Memetics is based on an analogy (Edmonds, 2005; Atrans, 2001). It does not have etymological roots and to date there is no way to test the analogies. Spiral dynamics is a management approach based on the meme-complex (Beck and Cowan, 1996). Here memes are systems of core values or collective intelligence that are active in any group. An organising principle, they act like an attractor for mini-memes aligned with its vibration. Beck and Cowan describe memes as the 'amino acids of our psycho-social "DNA" that act as the magnetic force which bind ideas into cohesive thought packages (p.11). Dawkins initiated interest in a phenomenon that needs discussion, study and critique but the lack of methodological framework and the fact that he is resting on analogies means that his work has tended to create confusion rather than clarity and has largely stalled in rigorous academic circles (Russ, 2014).

Russ (2014) links the metaphysical and western esoteric definitions of the phenomenon with memetics when she argues that Dawkins was attempting to define the metaphysical body of organisations when he coined the term meme-complex. Drawing from the cosmology of Plato, Russ argues that the organisational metaphysical body is a 'reflection of a perfect archetype into emanation through the power of the collective Will of people united in a joint purpose. It is the metaphysical body or the vehicle of thoughts and emotions for an organisation' (p.284). Russ argues that the metaphysical body emerges at the confluence of forces within intelligible realms. The definition proposed by Russ is the closest to that defined as the lexion, but it also lacks the links to linguistic roots.

\section{Discussion}


Researchers have attempted to describe and define the phenomenon of the lexion with greater and lesser success. The common theme is that definitions have generally been limited to defining the phenomenon as some form of collective or composite consciousness. A psychic being that is both created by and influences the people who make it up (Dubius, 2000; Delaforge, 1988; Bodeau, 1999; Heindel, 1909; Besant, 1912; Wink, 1986). Writers have discussed the phenomenon, its behaviour and its relationship to its members, but there has been no discussion that properly defines and understands its nature. The terms psychic entity of a group (Dubius, 2000), corporate being (Sagan, 2007), metabeing (Bodeau, 1999) and corporate angel (Wink, 1986) are helpful in that they suggest that there is a consciousness, a being, a group mind but these terms describe the phenomenon. With no linguistic roots and no theoretical framework, the term meme (rhyming with gene) tends to create confusion (Russ, 2014, p.21; Aunger, 2006; Edmonds, 2002; Atrans, 2001).

Currently there is no adequate term that describes the collective spirit behind ideologies, organisations, movements or nations. Current terms do not provide linguistic clues towards what or how the phenomenon comes into being, its structure or appropriate management. While current terms are useful in the context, they are limiting and at times misleading. No word has provided a theoretical structure and background for the phenomenon that is a lexion. No term recognises its true nature as an emanation of a lex, or archetype.

By introducing lexion, management consultants, corporations, movements and nations have a term that aligns with its etymological roots both practically and metaphysically. The metaphysical roots of lexion can be sourced to essences behind what is described as 'the Word' and 'law' in Greek and Latin respectively. The meaning matches the term. Terminology structures the nature of future discourse, according to Plato it creates and supports harmony within creation (Jowett 1891). Inappropriate terminology leads to misunderstandings and confusion. Lexion has etymological integrity and through its introduction to modern English, scholars have a term that facilitates rigorous and well founded discourse.

\section{Conclusion}

Lexion provides meaning that resonates through Latin, Greek, Hebrew, Arabic and English (Harper, 2014). This theoretical framework rests on the work of Heraclitus and Plato particularly, but many other scholars have contributed to the discourse and refined understandings. The definitions of lex and lexion are aligned with the original definitions which mean the term sits comfortably within languages that have been influenced by Ancient Greek or Latin.

Describing a lexion as that which upholds or bears an archetype is a modern definition that brings clarity to a phenomenon that has been shrouded in mystery. The association with esoteric schools, its lack of definition, the lack of a theoretical framework and the mysterious nature of the phenomenon itself has hindered open and rigorous discussion. Defining lex as an emanating archetype and the lexion as emerging at the confluence of forces aligned with the lex (archetype), describes the phenomenon in a way that is aligned with a vast tradition of scholarly research. Introduction of the terms lex and lexion provides a platform that allows the concept to emanate, to be discussed, critiqued and developed.

\section{References}

Arokiasamy, S. (1986). Dharma, Hindu and Christian according to Roberto de Nobili: Analysis of its meaning and its use in Hinduism and Christianity. Gregorian and Biblical Press. Retrieved from http://riccilibrary.usfca.edu/view.aspx?catalogID=352

Atran, S. (2001). The trouble with memes: inference versus imitation in cultural creation. Human Nature, 12(4), 351381. Retrieved from http://link.springer.com/article/10.1007\%2Fs12110-001-1003-0\#page-1

Aunger, R. (2006). 'What's the matter with memes?' Richard Dawkins: How a Scientist Changed the Way we Think: Reflections by Scientists, Writers, and Philosophers, ed. by Alan Grafen and Mark Ridley. Oxford: Oxford University Press.

Beck, D. E., \& Cowan, C. C. (1996). Spiral dynamics: Mastering values, leadership, and change: Exploring the new science of memetics. Cambridge, Mass., USA: Blackwell Business.

Beck, G. L. (1995). Sonic theology: Hinduism and sacred sound. Motilal Banarsidass Publ.

Besant, A. (1912). Man and his bodies (theosophical manual no. VII) (Second Edition ed.). Adyar, Theosophical Publishing House. Retrieved from http://www.anandgholap.net/Man_And_His_Bodies-AB.htm

Bloom, H. (1995). The Lucifer Principle: A scientific expedition into the forces of history. New York, New York: Atlantic Monthly Press.

Bodeau, D. (1999). Metabeings and individuals: Aids and obstacles to growth. Massachusetts USA: First Parish Unitarian-Universalist of Bedford. Retrievable online from http://www.anzam.org/wp-content/uploads/pdfmanager/562_ANZAM2011-313.PDF

Brodie, R. (1996). Virus of the mind: The new science of the meme. Integral Press.

Chroust, Anton-Hermann (1973) 'The Fundamental Ideas in St. Augustine's Philosophy of Law,' American Journal of Jurisprudence, 18(4). 
Coudert, A. P. (1995). Causation, Language, and the Kabbalah. In Leibniz and the Kabbalah (pp. 136-154). Springer Netherlands.

Dawkins, R. (2006). The selfish gene (First published in 1976. 30th anniversary edition, 3rd ed.). New York: Oxford University Press.

Day, T. P. (1982). The conception of punishment in early Indian literature. Ontario: Wilfrid Laurier University Press.

Delaforge, G. (1988). The Templar tradition: yesterday and today. Gnosis Magazine, 6, 8-14.

Dubuis, J. (2000). The fundamentals of esoteric knowledge. (B. Donvez Trans.). (Third ed.). Winfield IL USA. Triad Publishing. Retrieved from http://www.scribd.com/doc/23958243/Dubuis-Jean-The-Fundamentals-of-EsotericKnowledge\#scribd

Edmonds, B. (2002). Three challenges for the survival of memetics. Journal of Memetics-Evolutionary Models of Information Transmission. 6 (2), 45-50. Retrieved from http://connection.ebscohost.com/c/articles/7893837/threechallenges-survival-memetics

Edmonds, B. (2005). The revealed poverty of the gene-meme analogy —why memetics per se has failed to produce substantive results'. Journal of Memetics-Evolutionary Models of Information Transmission, 9 (1), 1-4. Retrieved from http://search.ebscohost.com/login.aspx?direct=true \&db=bth\&AN=17256475\&site=ehost-live

Harper, D. (2014). OnLine etymology dictionary. Retrieved from http://www.etymonline.com/index.php?allowed_in_frame=0\&search=lex\&searchmode=none

Heindel, M. (1909). The Rosicrucian Cosmo-Conception (Seventh ed.). Mt. Ecclesia, Oceanside, California, U.S.A: The Rosicrucian Fellowship International Headquarters.

Horsch, P. (2004). From creation myth to world law: The early history of dharma. Journal of Indian Philosophy, 32(56), 423-448. Retrieved from http://link.springer.com/article/10.1007/s10781-004-8628-3\#page-1

Jowett, B. (1891). The complete Plato. Translated by Benjamin Jowett (3rd Edition of Dialogues of Plato ed.). University of Adelaide Library: http://ebooks.adelaide.edu.au/p7plato/

Katz, S. B. (1995, July). The Kabbalah as a Theory of Rhetoric: Another Suppressed Epistemology. In Rhetoric, Cultural Studies, and Literacy: Selected Papers from the 1994 Conference of the Rhetoric Society of America (Vol. 6, p. 109). Psychology Press.

Kessler, F. (1944). 'Natural law, justice and democracy—some reflections on three types of thinking about law and justice'. Tul.L.Rev., 19, 32. Retrieved from

$\mathrm{http}$ //digitalcommons.law.yale.edu/cgi/viewcontent.cgi?article=3729\&context=fss_papers

Kretzmann, N. (1988). Lex iniusta non est lex-laws on trial in Aquinas' court of conscience. Am.J.Juris., $33,99$.

Langlois, W. G. (1971). Persistent voice: Essays on Hellenism in French literature since the 18th century, in honor of Professor Henri M. Peyre (First ed.). 11 Rue Massot Geneva: Librairie Droz.

Leadbeater, C. W. (1902). Theosophical manual. no. 6 the Devachanic plane or The Heaven World Its Characteristics And Inhabitants (Second Edition Ed.). London And Benares: The Theosophical Publishing Society. Retrieved from http://www.anandgholap.net/Devachanic_Plane-CWL.htm

Lentz, J. C. (1993). Luke's portrait of Paul. Cambridge UK: Cambridge University Press.

Lewis, C. T. (1891). An Elementary Latin Dictionary (Internet ed.). Internet Archive Franklin Square: Harper and Brothers.

Lewis, V. B. (2008). Higher law and the rule of law: The platonic origin of an ideal. Pepp.L.Rev., 36, 631-640.

Liddell, H. G., Scott, R., \& Jones, H. S. (Eds.). (1940). A Greek-English Lexicon/compiled by Henry George Liddell and Robert Scott (Perseus Digital Library ed.). Oxford: Clarendon Press. Retrieved from http://www.perseus.tufts.edu/hopper/text?doc=Perseus\%3Atext\%3A1999.04.0057\&redirect=true

Louth, A. (2007). The origins of the Christian mystical tradition: From Plato to Denys (Second ed.). New York: Oxford University Press.

McCullough, C. D. (1981). The concept of law in the thought of Erasmus. Erasmus of Rotterdam Society Yearbook, 1(1), 89-112. Retrived from http://booksandjournals.brillonline.com.ezproxy.uws.edu.au/content/journals/10.1163/187492781x00076

Miller, J. (1974). The Vedas. Harmony, meditation and fulfilment (First ed.). London: Rider \& Company.

Palmer, H. (1994). Living deliberately. Altamonte Springs Florida: Star Edge International.

Ramkumar, M. (2010). The Kautilya way. E-International Relations.

Rocher, L. (1977). Hindu conceptions of law. Hastings LJ, 29, 1283.

Rommen, H. A. (1998). The natural law: A study in legal and social history and philosophy Liberty Fund Inc.

Rose, N. (1998). Controversies in meme theory. Journal of Memetics-Evolutionary Models of Information

Transmission, 2(1), 43. Retrieved from

http://search.ebscohost.com/login.aspx?direct=true\&db=bth\&AN=2304871\&site=ehost-live 
Ruby, J. E. (1986). The origins of scientific law. Journal of the History of Ideas, 47(3), 341-359.

Russ, H. (2014). Memes and organisational culture; what is the relationship. (Doctoral dissertation) University of Western Sydney Press, University of Western Sydney.

Ryken, L., Wilhoit, J. C., \& Longman III, T. (Eds.). (2010). Dictionary of biblical imagery. InterVarsity Press.

Sagan, S. (2007). A language to map consciousness. Clairvision School. [Online] http://www.clairvision.org

Singh, R. (1963). Herakleitos and the law of nature. Journal of the History of Ideas, 457-472.

Smith, W. (1855). A smaller Latin-English dictionary: abridged from the larger dictionary. Oxford University Collection. John Murray Albemarle St London. Retrieved from https://archive.org/details/asmallerlatinen00smitgoog

Watson, A. (1991). Legal origins and legal change. (pp. Chapter 8) Continuum International Publishing Group.

Wilkins, J. S. (1998). 'What's in a meme? Reflections from the perspective of the history and philosophy of evolutionary biology'. Journal of Memetics, 2(1), 21.

Wink, W. (1986). Unmasking the powers: The invisible forces that determine human existence (First ed.). Philadelphia: Fortress Pr.

Wolfson, H. A. (1970). The Identification of ex nihilo with Emanation in Gregory of Nyssa. Harvard Theological Review, 63(01), 53-60.

Yonge, C. D. (1856). Phraseological Latin-English dictionary. London: Richard Bentley New Burlington St. Retrieved from https://archive.org/details/aphraseological00yonggoog

\section{Notes}

Following convention, capital letters have been used in several places to make a distinction in meaning. When referring to phenomenon at a non-manifested level a capital is used. When referring the manifested level a small case first letter is used. For example:

- The term perfect 'Form' refers to Plato's' archetype. The capital ' $F$ ', is used to differentiate it from a 'form' in the general sense.

- In a similar way, the 'Word' (capital W) refers to the creative impulse from which the creation emanates as opposed to the word in general usage.

- 'Will' is also given a capital letter, when it is used as a noun. When referring to the Will of people as a force of consciousness a capital is used. The capital is used to differentiate it from will as an auxiliary verb, as in I will come to the party.

- In a similar way to Form, Ideas are given a capital when referring to what Plato described as the world of Ideas.

- 'The One', and 'The Good" described by Plato uses capitals to differentiate it from conventional uses of the terms. 